\title{
A QUICK APPROACH FOR RHEOLOGICAL EVALUATION OF WARM ASPHALT BINDERS USING RESPONSE SURFACE METHOD
}

\author{
Meor Othman HAMZAH ${ }^{\mathrm{a}}$, Babak GOLCHIN ${ }^{\mathrm{b}}$, David WOODWARD ${ }^{\mathrm{c}}$ \\ ${ }^{a}$ School of Civil Engineering, Engineering Campus, Universiti Sains Malaysia,14300 Nibong Tebal, \\ Seberang Perai Selatan, Penang, Malaysia \\ ${ }^{b}$ Department of Civil Engineering, Ahar Branch, Islamic Azad University, Ahar, Iran \\ ${ }^{c}$ School of the Built Environment, University of Ulster, Newtownabbey, Co. Antrim, Northern Ireland
}

Received 20 Oct 2015; accepted 28 Jan 2016

\begin{abstract}
This paper describes a quick approach for quantification of the effects of a chemical warm named Rediset, and its interactions with temperature and aging on the rheological properties of asphalt binders using Response Surface Method. The central composite method was applied to design experimental programs for three test temperature conditions, namely; very high temperature $\left(120-180^{\circ} \mathrm{C}\right)$, high temperature $\left(46-82^{\circ} \mathrm{C}\right)$, and intermediate temperature $\left(19-31{ }^{\circ} \mathrm{C}\right)$. Rotational viscosity, $\mathrm{G}^{*} / \sin \delta$ and $\mathrm{G}^{*} \sin \delta$ were selected as parameters to assess the effects of the chemical warm additive on the rheological properties of asphalt binders for different aging conditions. Evaluation of the effects of this additive on the transformed value of $\mathrm{G}^{*} / \mathrm{sin} \delta$ at high temperatures indicates that additive content has significant effect on $\operatorname{Ln}\left(G^{*} / \sin \delta\right)$. The results for intermediate temperatures show that this additive has a positive effect on $G * \sin$ $\delta$ of asphalt binders.
\end{abstract}

Keywords: warm mix asphalt, viscosity, aging, fatigue, rutting, Response Surface Method.

\section{Introduction}

According to Mason et al. (2003), test procedures in engineering and scientific experiments are often guided by subjective consideration of practicality and established laboratory protocols. While these kinds of experiments are viewed economically based on the number of test runs, statistical approaches in design of experiments are used to ensure that experiments are designed by economic criteria. Response Surface Method (RSM) with the right number of test samples that can minimize the test efforts, has been used by researchers in other fields of knowledge as shown in Table 1. RSM is a mathematical and statistical method for designing experiments to establish relationships between multiple factors and to optimize the relevant conditions of parameters that enables prediction of the best set of responses (Nassar et al. 2016). Since asphalt laboratory works need more efforts and costs, RSM can open a new approach for the asphalt material technologist to quickly determine the effects of new developed additives on asphalt material properties. With this in mind, RSM was used to evaluate the influence of a chemical warm mix additive, named Rediset on the rheological properties of asphalt binders.

Rediset is a poly functional additive based on fatty amine surfactants (Smiljanic et al. 2011). According to Banerjee et al. (2012), Rediset can reduce the compac- tion and mixing temperatures of asphalt mixtures by as much as $35^{\circ} \mathrm{C}$. The use of this additive can decrease both fuel consumption and emissions from asphalt plants and hence can be considered as an environmentally sustainable technology (Hamzah, Golchin 2013). In the past, some rheological properties of asphalt binders containing only a fixed dosage of Rediset have been investigated (Arega et al. 2011; Bennert et al. 2011; Xiao et al. 2012a, $2012 b$ ). Previous researches have only investigated the main effects of WMA additives at the dosages recommended by their suppliers without consideration of the quantification effect of additive content and its interaction with other factors. Therefore, the influence of Rediset contents and its interactions with aging conditions and test temperatures on the rheological properties of two asphalt binders were investigated using RSM. According to Hamzah et al. (2015), Rediset is categorised under chemical warm additive. Its mechanism of temperature reduction is rather complicated. Therefore, it is necessary to analyze its performance on the rheological properties of binders using Superpave rutting and fatigue factors as well as its viscosity using the dynamic shear rheometer and viscometer, respectively.

RSM is a collection of statistical tools for designing experiments, developing models, assessing the effects of

Corresponding author: Meor Othman Hamzah

E-mail:cemeor@yahoo.com 
Table 1. Use of RSM in some applied sciences

\begin{tabular}{clllccc}
\hline No. & \multicolumn{1}{c}{ Material } & \multicolumn{1}{c}{ Software used } & $\begin{array}{c}\text { Design } \\
\text { method }\end{array}$ & $\begin{array}{c}\text { Design } \\
\text { factors }\end{array}$ & $\begin{array}{c}\text { Number of } \\
\text { responses }\end{array}$ & References \\
\hline 1 & Cement & - & CCD* & 3 & 10 & Sonebi and Bassuoni (2013) \\
2 & Asphalt mixture & Minitab: Release15 & CCD & 2 & 3 & Khodaii et al. (2012) \\
3 & Palm fruit & Design-Expert & CCD & 3 & 2 & Goh et al. (2011) \\
4 & Aluminum & Design-Expert & CCD & 3 & 1 & Faseeulla Khan et al. (2012) \\
5 & Chitason film & - & BBD** & 3 & 3 & Srinivasa et al. (2007) \\
6 & Pulley & - & CCD & 2 & 2 & Shim and Kim (2008) \\
7 & Clay & - & - & $2,2,3$ & $3,6,6$ & Boylu (2011) \\
8 & Cement & Nemrod -W & OCD*** & 3 & 4 & Chakchouk et al. (2009) \\
9 & Concrete & Design-Expert & - & 2 & 7 & Akcay and Tasdemir (2009) \\
10 & Asphalt mixture & Design-Expert & CCD & 3 & 6 & Hamzah et al. (2013) \\
\hline Notes: & $*$ Central Composite Design. & & & &
\end{tabular}

experimental factors, and optimizing the model-building process (Kim et al. 2010; Kushwaha et al. 2010). This method has been recently used in asphalt binder and mixture studies (Chavez-Valencia et al. 2007; Khodaii et al. 2012; Hamzah et al. 2013). Table 1 presents the successful usage of RSM for characterization of material properties in some applied sciences. This fact and also scientific supports for RSM in statistical handbooks, reveals that RSM can be a new and effective approach for rheological characterization of warm asphalt binders.

Since the objective of this research was the use of a quick approach for rheological evaluation of warm asphalt binders, the principles of RSM were used for design of experiments and data analysis. Based on this method, several simple experimental designs were developed and various simple rheological laboratory tests were performed. Two-factor interaction and quadratic regression models were selected based on the sequential F-tests, lack-of-fit tests and other adequacy measures for quantification of the effect of the Rediset content on the asphalt binder properties. The significance of design factors (additive content, test temperature, binder type, and aging condition) and their interactions on response values (rotational viscosity, $\mathrm{G}^{*} / \sin \delta$, and $\mathrm{G}^{*} \sin \delta$ ) were evaluated using analysis of variance (ANOVA). Model graphs were then generated based on appropriate regression equations for interpretations of results. Figure 1 shows a schematic form of this research work.

\section{Materials and methods}

\subsection{Materials}

Two asphalt binders, PG64 and PG76, were selected for use in this study. PG refers to the performance grade of binder developed in the United States for characterizing asphalt binders. Rediset was chosen as a warm-mix asphalt additive to investigate its effect on these binders. Rediset is a chemical warm-mix additive and is produced by Akzonobel in the Netherlands. According to Hamzah et al. (2015), Rediset is a combination of fatty polyamines, polymer and non-ionic components. This additive is made up of a long chain of aliphatic hydrocarbon structure and an -NH3+ group which chemically reacts with aggregate surfaces. It is marketed as a warm mix additive with adhesion promoting properties. In addition to being a typical warm additive, it also acts as an antistriping agent, antioxidant and an additive that facilitates compaction. The properties of the asphalt binders are presented in Table 2.

\subsection{Samples preparation}

Asphalt binders, PG64 and PG76, were heated to $130{ }^{\circ} \mathrm{C}$ and $180{ }^{\circ} \mathrm{C}$ for blending with Rediset, respectively.

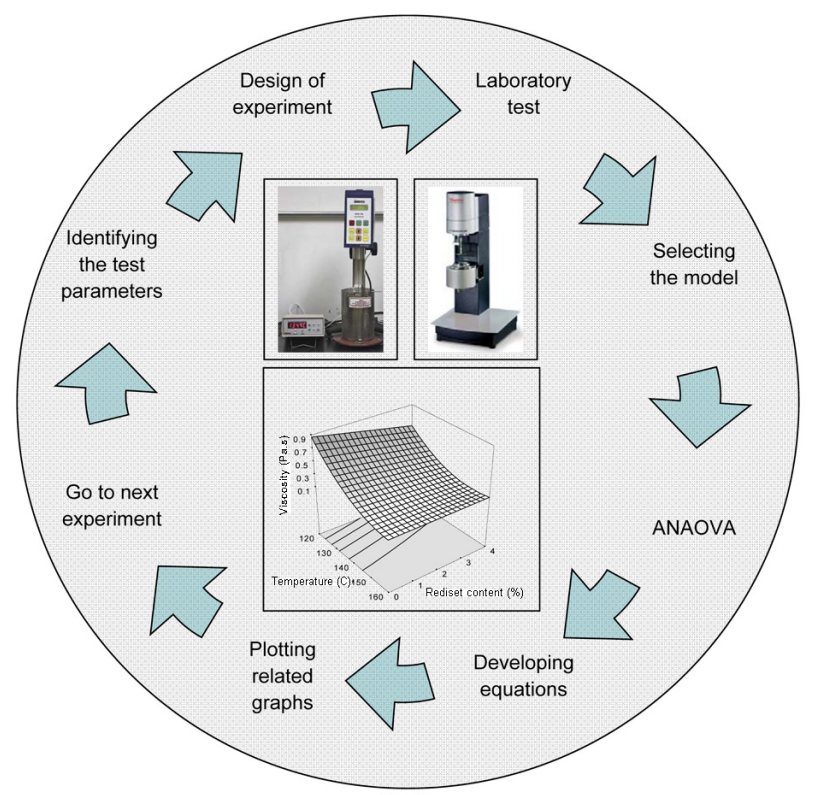

Fig. 1. A schematic sketch of research work 
Table 2. Properties of asphalt binders

\begin{tabular}{|c|c|c|c|}
\hline \multirow{2}{*}{ Aging condition } & \multirow{2}{*}{ Properties } & \multicolumn{2}{|c|}{ Asphalt binder } \\
\hline & & PG64 & PG76 \\
\hline \multirow[t]{6}{*}{ Original binder } & Viscosity at $135^{\circ} \mathrm{C}$ (Pa.s) & 0.38 & 1.66 \\
\hline & Softening point $\left({ }^{\circ} \mathrm{C}\right)$ & 45 & 69 \\
\hline & Penetration $(0.1 \mathrm{~mm})$ & 80 & 50 \\
\hline & Ductility $(\mathrm{cm})$ & $>100$ & 90 \\
\hline & Flash point $\left({ }^{\circ} \mathrm{C}\right)$ & 331 & 344 \\
\hline & $\mathrm{G}^{*} / \sin \delta$ at $\mathrm{PG}$ temperature $(\mathrm{Pa})$ & 1653 & 2374 \\
\hline Short-term aged binder (RTFO) & $\mathrm{G}^{*} / \sin \delta$ at $\mathrm{PG}$ temperature $(\mathrm{Pa})$ & 2442 & 3968 \\
\hline Long-term aged binder (RTFO+PAV) & $\mathrm{G}^{*}(\sin \delta)$ at $25^{\circ} \mathrm{C}(\mathrm{MPa})$ & 2.58 & 5.41 \\
\hline
\end{tabular}

Rediset was blended into the hot asphalt binders using a low-shear stirrer for 30 minutes at $60 \mathrm{rpm}$. The blended binders were then subjected to artificial short-term aging in accordance with ASTM D2872 (2006) procedures using the rolling thin-film oven (RTFO). A pressure aging vessel (PAV) was used for long-term aging of the binders in accordance with ASTM D6521 (2006) using the artificially short-term-aged binders.

\subsection{Experimental designs}

Three sets of experiments were designed using the central composite method to characterize the properties of asphalt binders containing Rediset (see Tables 3-5 for some selected condition). Central composite design is an alternative form of the $3 \mathrm{k}$ factorial experiment design that consists of $2 \mathrm{k}$ factorial design, center point, and two axial points on the axis of each design variable (Khuri, Cornell 1996). The $3 \mathrm{k}$ factorial experiment design is an experiment with $\mathrm{k}$ quantitative variable at three levels. In the first set of experiments (see Table 3), the test temperature, Rediset content, and aging condition (unaged and shortterm-aged) were selected as independent variables, while the rotational viscosity was defined as the response. The rotational viscosity was measured at temperatures from $120{ }^{\circ} \mathrm{C}$ to $160{ }^{\circ} \mathrm{C}$ and $140{ }^{\circ} \mathrm{C}$ to $180{ }^{\circ} \mathrm{C}$ for PG64 and PG76 asphalt binders, respectively. In the second set of experiments (see Table 4), independent variables from the first set of experiment and also binder type were defined as the main parameters of the experiment, while $\mathrm{G}^{*} /$ $\sin \delta$ (Superpave rutting factor) and its transformed value $\left(\mathrm{Ln}\left(\mathrm{G}^{*} / \sin \delta\right)\right)$ were defined as the responses. The $\mathrm{G}^{* /}$ $\sin \delta$ was measured at temperatures from 46 to $82^{\circ} \mathrm{C}$. In the third set of experiments (see Table 5), the independent variables were the Rediset content, test temperature, and binder type and $\mathrm{G}^{*} \sin \delta$ was defined as the response. This value was measured at temperatures between 19 and $31{ }^{\circ} \mathrm{C}$ under long-term-aging conditions. All of the tests were performed on binder samples containing 0 to $4 \%$ Rediset.

\subsection{Laboratory tests}

The effects of Rediset content on the rheological properties of the aged and unaged warm binder samples were investigated in terms of $\mathrm{G}^{*} / \sin \delta$ and viscosity (for unaged and short-term age condition) and $\mathrm{G}^{*} \sin \delta$ (for
Table 3. Experiment matrix for rotational viscosity

\begin{tabular}{|c|c|c|c|c|c|}
\hline 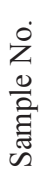 & 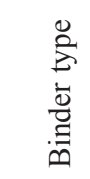 & 里: & 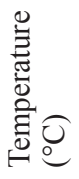 & 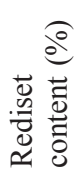 & 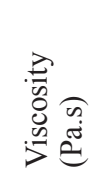 \\
\hline 1 & PG64 & Unaged & 140 & 2 & 0.25 \\
\hline 2 & PG64 & Unaged & 140 & 0 & 0.31 \\
\hline 3 & PG64 & Unaged & 120 & 4 & 0.58 \\
\hline 4 & PG64 & Unaged & 160 & 4 & 0.1 \\
\hline 5 & PG64 & Unaged & 140 & 2 & 0.25 \\
\hline 6 & PG64 & Unaged & 140 & 4 & 0.21 \\
\hline 7 & PG64 & Unaged & 140 & 2 & 0.26 \\
\hline 8 & PG64 & Unaged & 160 & 0 & 0.13 \\
\hline 9 & PG64 & Unaged & 120 & 2 & 0.66 \\
\hline 10 & PG64 & Unaged & 160 & 2 & 0.11 \\
\hline 11 & PG64 & Unaged & 120 & 0 & 0.87 \\
\hline 12 & PG64 & Short-term aged & 140 & 2 & 0.3 \\
\hline 13 & PG64 & Short-term aged & 120 & 2 & 0.86 \\
\hline 14 & PG64 & Short-term aged & 160 & 2 & 0.13 \\
\hline 15 & PG64 & Short-term aged & 120 & 0 & 1.1 \\
\hline 16 & PG64 & Short-term aged & 140 & 0 & 0.38 \\
\hline 17 & PG64 & Short-term aged & 160 & 4 & 0.13 \\
\hline 18 & PG64 & Short-term aged & 160 & 0 & 0.16 \\
\hline 19 & PG64 & Short-term aged & 140 & 2 & 0.3 \\
\hline 20 & PG64 & Short-term aged & 120 & 4 & 0.73 \\
\hline 21 & PG64 & Short-term aged & 140 & 2 & 0.31 \\
\hline 22 & PG64 & Short-term aged & 140 & 4 & 0.26 \\
\hline 23 & PG76 & Unaged & 180 & 2 & 0.2833 \\
\hline 24 & PG76 & Unaged & 160 & 2 & 0.5875 \\
\hline 25 & PG76 & Unaged & 180 & 4 & 0.275 \\
\hline 26 & PG76 & Unaged & 160 & 4 & 0.5125 \\
\hline 27 & PG76 & Unaged & 160 & 2 & 0.575 \\
\hline 28 & PG76 & Unaged & 140 & 2 & 1.1543 \\
\hline 29 & PG76 & Unaged & 140 & 4 & 1 \\
\hline 30 & PG76 & Unaged & 180 & 0 & 0.2917 \\
\hline 31 & PG76 & Unaged & 160 & 2 & 0.575 \\
\hline 32 & PG76 & Unaged & 140 & 0 & 1.3125 \\
\hline 33 & PG76 & Unaged & 160 & 0 & 0.6625 \\
\hline 34 & PG76 & Short-term aged & 180 & 4 & 0.25 \\
\hline 35 & PG76 & Short-term aged & 140 & 4 & 1.171 \\
\hline 36 & PG76 & Short-term aged & 160 & 4 & 0.517 \\
\hline 37 & PG76 & Short-term aged & 160 & 2 & 0.625 \\
\hline 38 & PG76 & Short-term aged & 160 & 2 & 0.663 \\
\hline 39 & PG76 & Short-term aged & 180 & 2 & 0.3 \\
\hline 40 & PG76 & Short-term aged & 160 & 2 & 0.65 \\
\hline 41 & PG76 & Short-term aged & 180 & 0 & 0.372 \\
\hline 42 & PG76 & Short-term aged & 140 & 2 & 1.429 \\
\hline 43 & PG76 & Short-term aged & 140 & 0 & 1.908 \\
\hline 44 & PG76 & Short-term aged & 160 & 0 & 0.816 \\
\hline
\end{tabular}


Table 4. Experiment matrix for $\mathrm{G} / \sin \delta$

\begin{tabular}{ccclll}
\hline \multirow{2}{*}{$\begin{array}{c}\text { Sample } \\
\text { No. }\end{array}$} & $\begin{array}{c}\text { Temperature } \\
\left({ }^{\circ} \mathrm{C}\right)\end{array}$ & $\begin{array}{c}\text { Rediset content } \\
(\%)\end{array}$ & Aging condition & \multicolumn{2}{c}{$\mathrm{G}^{*} / \sin \delta(\mathrm{kPa})$} \\
\cline { 5 - 6 } & 82 & 2 & Unaged & 0.2 & 0.85 \\
2 & 82 & 0 & Unaged & 0.19 & 0.98 \\
3 & 64 & 2 & Unaged & 1.61 & 6.49 \\
4 & 64 & 2 & Unaged & 1.49 & 6.10 \\
5 & 82 & 4 & Unaged & 0.27 & 0.76 \\
6 & 46 & 2 & Unaged & 22.81 & 43.96 \\
7 & 46 & 0 & Unaged & 26.8 & 43.99 \\
8 & 46 & 4 & Unaged & 23.02 & 37.255 \\
9 & 64 & 4 & Unaged & 1.93 & 5.54 \\
10 & 64 & 0 & Unaged & 1.65 & 7.17 \\
11 & 64 & 2 & Unaged & 1.56 & 6.21 \\
12 & 64 & 2 & Short-term aged & 2.39 & 11.46 \\
13 & 64 & 2 & Short-term aged & 2.41 & 12.04 \\
14 & 82 & 0 & Short-term aged & 0.25 & 1.95 \\
15 & 46 & 0 & Short-term aged & 41.29 & 88.82 \\
16 & 64 & 2 & Short-term aged & 2.44 & 11.25 \\
17 & 64 & 4 & Short-term aged & 2.32 & 8.61 \\
18 & 46 & 4 & Short-term aged & 33.1 & 66.06 \\
19 & 82 & 2 & Short-term aged & 0.27 & 1.60 \\
20 & 82 & 4 & Short-term aged & 0.32 & 1.15 \\
21 & 64 & 0 & Short-term aged & 2.44 & 13.205 \\
22 & 46 & 2 & Short-term aged & 38.56 & 88.28 \\
\hline
\end{tabular}

Table 5. Experiment matrix for $\mathrm{G}^{*} \sin \delta$

\begin{tabular}{ccccc}
\hline \multirow{2}{*}{$\begin{array}{c}\text { Sample } \\
\text { No. }\end{array}$} & $\begin{array}{c}\text { Temperature } \\
\left({ }^{\circ} \mathrm{C}\right)\end{array}$ & $\begin{array}{c}\text { Rediset content } \\
(\%)\end{array}$ & \multicolumn{2}{c}{$\begin{array}{c}\text { G*(sin } \delta) \\
(\mathrm{MPa})\end{array}$} \\
\cline { 4 - 5 } & & 0 & 4.62 & 7.31 \\
2 & 19 & 4 & 1.97 & 2.84 \\
3 & 25 & 2 & 2.59 & 4.03 \\
4 & 25 & 4 & 0.99 & 1.71 \\
5 & 31 & 2 & 1.09 & 2.47 \\
6 & 31 & 4 & 3.55 & 4.25 \\
7 & 19 & 0 & 2.58 & 5.41 \\
8 & 25 & 0 & 1.29 & 3.57 \\
9 & 31 & 2 & 2.24 & 3.87 \\
10 & 25 & 2 & 2.23 & 4.32 \\
11 & 25 & 2 & 4.18 & 4.60 \\
\hline
\end{tabular}

long-term age condition). Dynamic shear modulus $\left(\mathrm{G}^{*}\right)$ and phase angle $(\delta)$ were measured in accordance with ASTM D7175-08 (2011). Rotational viscosity test was conducted on both unaged and short-term-aged asphalt binder samples containing Rediset using rotational viscometer based on ASTM D4402-02 (2011).

\subsection{Analysis methods}

RSM is the application of the regression models as well as experiment design methods, and other techniques to understand the behavior of the responses of the system under the study. In this research for developing a regression model for each response (viscosity, $G^{*} / \sin \delta$ and $\mathrm{G}^{*} \sin \delta$ ), linear, quadratic and two-factor interaction regression models were evaluated using sequential F-tests, lack-of-fit tests, and R-square value. For the selected regression model, the significance of each factor (linear, quadratic and interaction terms) was examined by analysis of variance (ANOVA). Insignificant factors were discarded and proposed models were used for predicting the responses. These analyses were conducted using the Design-Expert 6.0.6 software. Eqns (1)-(3) show mathematical forms of linear, two-factor interactions, and quadratic regression models, respectively:

$$
\begin{gathered}
Y=b_{0}+\sum_{i=1}^{n} b_{i} X_{i} ; \\
Y=b_{0}+\sum_{i=1}^{n} b_{i} X_{i}+\sum_{i=1}^{n-1} \sum_{j=i+1}^{n} b_{i j} X_{i} X_{j} ; \\
Y=b_{0}+\sum_{i=1}^{n} b_{i} X_{i}+\sum_{i=1}^{n} b_{i i} X_{i i}^{2}+\sum_{i=1}^{n-1} \sum_{j=i+1}^{n} b_{i j} X_{i} X_{j} .
\end{gathered}
$$


In these models, $Y$ is the response variable and $b_{0}$, $b_{i}, b_{i i}$, and $b_{i j}$ are constant coefficient of intercept, linear, quadratic, and interaction terms respectively while $X_{i}$ and $X_{j}$ are independent numeric variables.

\section{Results and discussions}

\subsection{Effects of Rediset on viscosity}

Some results of the rotational viscosity tests based on the experimental designs are given in Table 3. Results show for both asphalt binders and aging conditions, rotational viscosity decreases as Rediset content and test temperature increase. Lower viscosity may imply a better workability and compactability for asphalt mixtures at mixing and compaction temperatures.

For quantification of the effects of the test parameters on the viscosity and also fitting functions for predicting rotational viscosity to the data, three regression models (linear, two-factor interaction, and quadratic) were evaluated using sequential F-tests, lack-of-fit tests, and R-square values for both asphalt binders (see Table 6).The results showed that a quadratic model has high $\mathrm{R}$-square value as well as high p-value in the lack of fit test. As shown in Table 6, this model exhibits an acceptable low p-value in sequential F-tests.

Analysis of variance (ANOVA) was conducted to identify significant factors and interactions. The results of the ANOVA are presented in Table 7. A "Prob > F" value less than 0.05 is indicative of a statistically significant main effect or interaction. From Table 7, test temperature, Rediset content, aging condition, binder type, and the second-order term of test temperature, as well as the interactions of test temperature with Rediset content and aging condition for both asphalt binder exhibit significant effects on the measured rotational viscosity. Comparison of the F values in Table 7 shows that the degree of significance of Rediset content is lower than that of test temperature and greater than that of the aging parameter.

The proposed models for rotational viscosity of unaged and short-term-aged conditions are expressed by Eqns (4) and (5) for both asphalt binders:

$$
\begin{aligned}
& \text { Viscosity }_{P G 64}=\left\{\begin{array}{r}
11.7453-0.1447 A-0.3016 B+0.0018(A \times B)+0.0004 A^{2}(\text { unaged }) \\
12.4132-0.1489 A-0.3016 B+0.0018(A \times B)+0.0004 A^{2}(\text { short-termaged })
\end{array} ;\right. \\
& \text { Viscosity }_{P G 76}=\left\{\begin{array}{r}
17.4397-0.1826 A-0.4953 B+0.0028(A \times B)+0.0004 A^{2}(\text { unaged }) \\
18.9789-0.1906 A-0.5519 B+0.0028(A \times B)+0.0004 A^{2}(\text { short-termaged })
\end{array}\right.
\end{aligned}
$$

\begin{tabular}{|c|c|c|c|c|c|c|}
\hline Title & sum of Squares & $\mathrm{DF}^{*}$ & Mean Square & F Value & Prob $>$ F & Model type \\
\hline Viscosity & \multicolumn{6}{|c|}{ (PG64 from $120^{\circ} \mathrm{C}$ to $160^{\circ} \mathrm{C}$ ) } \\
\hline Regression & 1.47 & 3 & 0.49 & 34.26 & $<0.0001$ & Linear \\
\hline Lack of fit & 0.257845 & 14 & 0.018418 & 552.526 & $<0.0001$ & \\
\hline R-squared & 0.85 & & & & & \\
\hline Regression & 0.067 & 3 & 0.022 & 1.74 & 0.2013 & $2 \mathrm{FI}$ \\
\hline Lack of fit & 0.191179 & 11 & 0.01738 & 521.3967 & $<0.0001$ & \\
\hline R-squared & 0.89 & & & & & \\
\hline Regression & 0.18 & 2 & 0.090 & 106.30 & $<0.0001$ & Quadratic \\
\hline Lack of fit & 0.011 & 9 & $1.210 \mathrm{E}-003$ & 36.30 & 0.0018 & \\
\hline R-squared & 0.99 & & & & & \\
\hline Viscosity & \multicolumn{6}{|c|}{ (PG76 from $140{ }^{\circ} \mathrm{C}$ to $180{ }^{\circ} \mathrm{C}$ ) } \\
\hline Regression & 3.53 & 3 & 1.18 & 44.92 & $<0.0001$ & Linear \\
\hline Lack of fit & 0.47 & 14 & 0.034 & 158.08 & $<0.0001$ & \\
\hline R-squared & 0.88 & & & & & \\
\hline Regression & 0.22 & 3 & 0.073 & 4.39 & 0.0208 & $2 \mathrm{FI}$ \\
\hline Lack of fit & 0.25 & 11 & 0.023 & 106.93 & 0.0002 & \\
\hline R-squared & 0.94 & & & & & \\
\hline Regression & 0.21 & 2 & 0.1 & 31.32 & $<0.0001$ & Quadratic \\
\hline Lack of fit & 0.042 & 9 & $4.70 \mathrm{E}-03$ & 22.1 & 0.0046 & \\
\hline R-squared & 0.99 & & & & & \\
\hline
\end{tabular}

Table 6. Regression models for prediction of viscosity of binders 


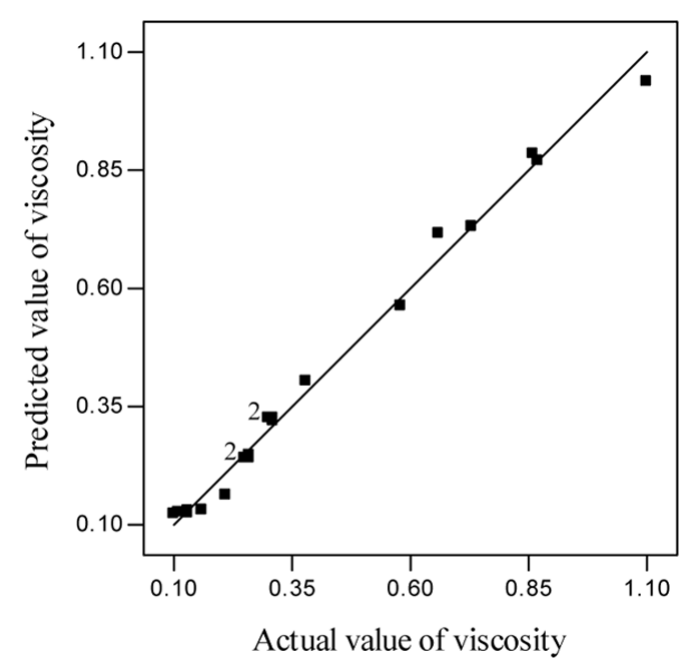

Fig. 2. Predicted and actual values of viscosity

where $A$ and $B$ are test temperatures $\left({ }^{\circ} \mathrm{C}\right)$ and Rediset content (\%), respectively. According to the regression coefficients of Eqns (4) and (5), increasing Rediset content decreases the rotational viscosity of asphalt binder for both unaged and short-term-aged conditions. This positive effect of Rediset in decreasing binder viscosity has also been reported by Xiao et al. (2012a) and Arega et al. (2011). In addition, Eqns (4) and (5) show that the Rediset content and the interaction of Rediset content with temperature has inverse effects. Based on the results of the ANOVA for rotational viscosity shown in Table 7, the interaction of Rediset content with temperature is judged to be statistically significant, but the degree of its significance is lower than that of Rediset content ( $\mathrm{F}$ value of $A B$ is lower than that of $B$ in Table 7 for viscosity data). Plots of predicted versus actual values of rotational viscosity are shown in Figure 2. Figure 3 shows the response surface of rotational viscosity versus Rediset content and temperature for unaged conditions.

Figure 4(a) illustrates the interaction effect between Rediset content and temperature for PG64 under unaged condition. Increasing the Rediset content from 0 to $4 \%$ decreases the rotational viscosity at $120^{\circ} \mathrm{C}$, but this range of variation of Rediset content has little effect on the viscosity at $160{ }^{\circ} \mathrm{C}$. This means that the effects of Rediset content on rotational viscosity at $120^{\circ} \mathrm{C}$ is greater than that at $160^{\circ} \mathrm{C}$. A similar trend exists for short-term-aged conditions and PG76 binder. It implies that the effects of Rediset on the viscosity of PG76 binder at $140{ }^{\circ} \mathrm{C}$ is higher compared to the effects on viscosity at $180^{\circ} \mathrm{C}$. In Figure 4(b), the interaction effect of Rediset content and aging condition at $140{ }^{\circ} \mathrm{C}$ is illustrated for PG64. The rates of change in viscosity for unaged and short-termaged conditions are similar. This indicates that there is no interaction between Rediset content and aging condition for PG64. This fact can be confirmed by the ANOVA results in Table 7.
Table 7. Analysis of variance for viscosity, $\mathrm{G}^{*} / \sin \delta$ and $\mathrm{G}^{*} \sin \delta$

\begin{tabular}{|c|c|c|c|c|}
\hline Viscosity & PG64 & & & \\
\hline Factor* & Sum of Squares & $\mathrm{DF}^{* *}$ & F value & Prob $>F$ \\
\hline $\mathrm{A}$ & 1.36 & 1 & 1603.92 & $<0.0001$ \\
\hline $\mathrm{B}$ & 0.074 & 1 & 86.83 & $<0.0001$ \\
\hline $\mathrm{C}$ & 0.039 & 1 & 46.36 & $<0.0001$ \\
\hline$A^{2}$ & 0.15 & 1 & 180.78 & $<0.0001$ \\
\hline $\mathrm{B}^{2}$ & $2.906 \mathrm{E}-003$ & 1 & 3.43 & 0.0870 \\
\hline $\mathrm{AB}$ & 0.045 & 1 & 53.07 & $<0.0001$ \\
\hline $\mathrm{AC}$ & 0.021 & 1 & 24.57 & 0.0003 \\
\hline $\mathrm{BC}$ & 8.333E-004 & 1 & 0.98 & 0.3396 \\
\hline Viscosity & PG76 & & & \\
\hline Factor & Sum of Squares & DF & $\mathrm{F}$ value & Prob $>$ F \\
\hline $\mathrm{A}$ & 3.21 & 1 & 966.71 & $<0.0001$ \\
\hline $\mathrm{B}$ & 0.22 & 1 & 67.35 & $<0.0001$ \\
\hline $\mathrm{C}$ & 0.098 & 1 & 29.68 & 0.0001 \\
\hline $\mathrm{A}^{2}$ & 0.18 & 1 & 53.84 & $<0.0001$ \\
\hline $\mathrm{B}^{2}$ & 2.699E-003 & 1 & 0.81 & 0.3834 \\
\hline $\mathrm{AB}$ & 0.10 & 1 & 31.26 & $<0.0001$ \\
\hline $\mathrm{AC}$ & 0.078 & 1 & 23.60 & 0.0003 \\
\hline $\mathrm{BC}$ & 0.038 & 1 & 11.58 & 0.0047 \\
\hline \multicolumn{5}{|c|}{$\operatorname{Ln}(G * / \sin \delta)$} \\
\hline Factor & Sum of Squares & DF & F value & Prob $>F$ \\
\hline $\mathrm{A}$ & 114.24 & 1 & 6764.13 & $<0.0001$ \\
\hline $\mathrm{B}$ & 0.11 & 1 & 6.30 & 0.0175 \\
\hline $\mathrm{C}$ & 2.54 & 1 & 150.20 & $<0.0001$ \\
\hline $\mathrm{D}$ & 17.27 & 1 & 1022.59 & $<0.0001$ \\
\hline$A^{2}$ & 0.21 & 1 & 12.15 & 0.0015 \\
\hline $\mathrm{B}^{2}$ & $2.930 \mathrm{E}-005$ & 1 & $1.735 \mathrm{E}-003$ & 0.9670 \\
\hline $\mathrm{AB}$ & 0.027 & 1 & 1.57 & 0.2195 \\
\hline $\mathrm{AC}$ & 0.028 & 1 & 1.63 & 0.2105 \\
\hline $\mathrm{AD}$ & 1.18 & 1 & 69.74 & $<0.0001$ \\
\hline $\mathrm{BC}$ & 0.038 & 1 & 2.24 & 0.1442 \\
\hline $\mathrm{BD}$ & 0.21 & 1 & 12.62 & 0.0012 \\
\hline $\mathrm{CD}$ & 0.16 & 1 & 9.37 & 0.0045 \\
\hline
\end{tabular}

\begin{tabular}{ccclc}
\hline \multicolumn{6}{l}{$\mathbf{G}(\sin \boldsymbol{\delta})$} & \multicolumn{3}{l}{} \\
\hline Factor & Sum of Squares & DF & F value & Prob $>$ F \\
\hline A & 25.20 & 1 & 259.35 & $<0.0001$ \\
B & 7.47 & 1 & 76.91 & $<0.0001$ \\
D & 13.21 & 1 & 135.99 & $<0.0001$ \\
AB & 0.49 & 1 & 4.99 & $<0.0001$ \\
AD & 0.027 & 1 & 0.28 & 0.0411 \\
BD & 2.53 & 1 & 26.04 & 0.6053 \\
\hline
\end{tabular}

Notes: *, A, Testing temperature; B, Rediset content;

C, Aging condition; D, Binder type;

**, Degree of freedom. 


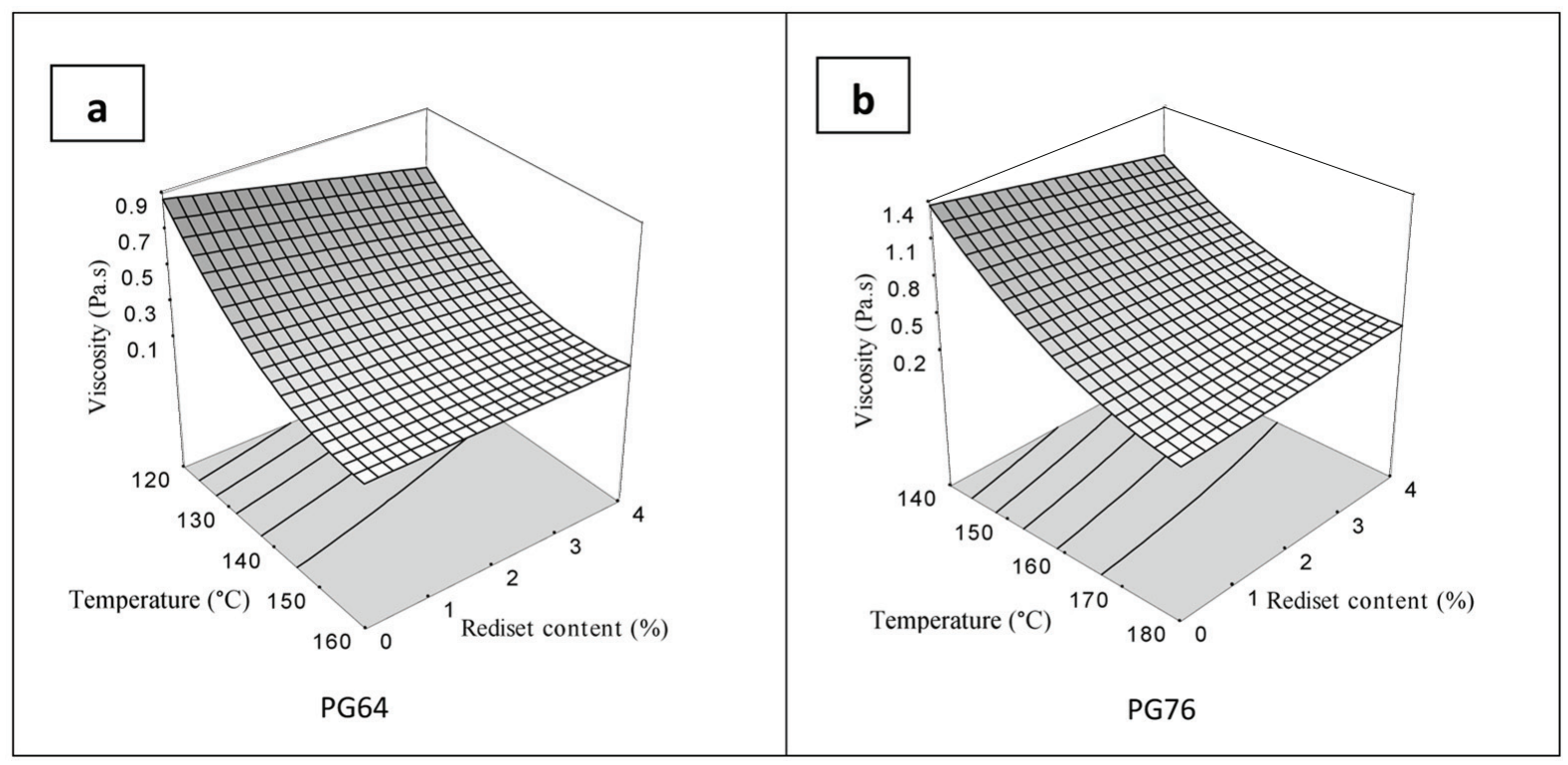

Fig. 3. Plot of response surface for the viscosity value for unaged conditions

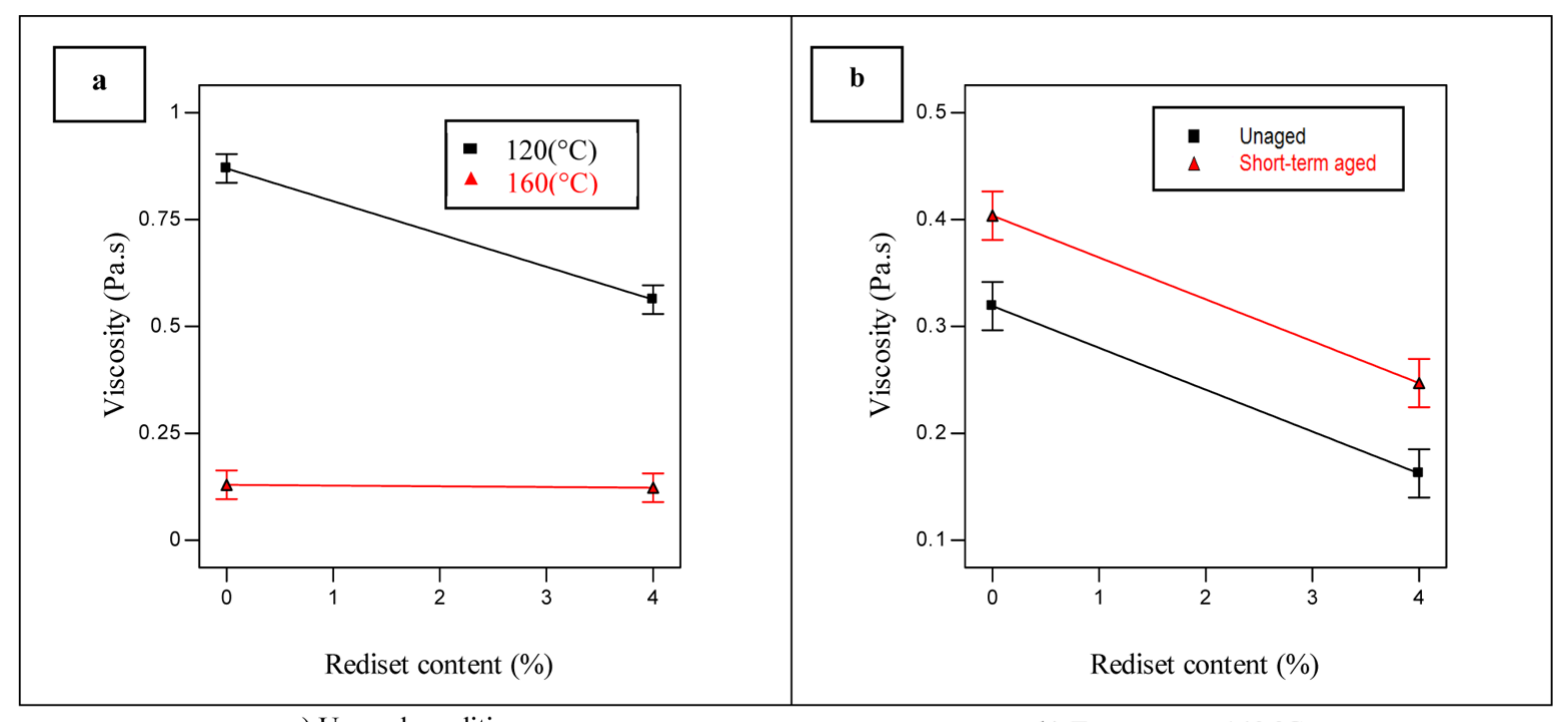

a) Unaged condition

b) Temperature $140^{\circ} \mathrm{C}$

Fig. 4. Interaction effects of Rediset with temperature and aging condition on the value of viscosity for PG64

\subsection{Effects of Rediset on $G^{*} / \sin \delta$}

Measurements of $\mathrm{G}^{*} / \sin \delta$ for both binders under unaged and short-term aging conditions based on the experimental designs are given in Table 4 . The results showed that, Rediset does not exhibit noticeable change in $\mathrm{G}^{*} / \sin \delta$ at high performance temperatures. As expected, the $\mathrm{G}^{*} / \sin \delta$ for PG76 and short-term aging condition are higher than the corresponding values for PG64 and unaged condition. Higher $\mathrm{G}^{*} / \sin \delta$ implies higher stiffness properties for asphalt binders at high performance temperatures.

Analysis based on RSM was conducted on the laboratory test results of $\mathrm{G}^{*} / \sin \delta$. The results showed that Rediset content does not statistically have significant effect on the $G^{*} / \sin \delta$. Thus, the transformed value of responses $\left(\mathrm{Ln}\left(\mathrm{G}^{*} / \sin \delta\right)\right)$ were used for developing the models. According to analysis, quadratic regression models were selected to quantify the effects of Rediset content and test temperature. The results of the statistical analysis for selected model are shown in Table 8.

The results of the ANOVA for $\mathrm{Ln}\left(\mathrm{G}^{*} / \mathrm{sin} \delta\right)$ are given in Table 7. A P-value less than 0.05 is indicative of a statistically significant main effect or interaction. Table 7 shows that test temperature, Rediset content, aging condition, binder type, and the second-order term of test temperature exhibit statistically significant effects on the measured value of $\operatorname{Ln}\left(\mathrm{G}^{*} / \sin \delta\right)$. The proposed models for unaged and short-term aging conditions are expressed by Eqns (6) and (7), respectively: 


$$
\begin{gathered}
\operatorname{Ln}\left(G^{*} / \sin \delta\right)_{\text {unaged }}=\left\{\begin{array}{l}
10.9217-0.1899 A+0.0138 B+0.0004 A^{2}(P G 64) \\
10.6679-0.1653 A-0.0804 B+0.0004 A^{2}(P G 76)
\end{array}\right. \\
\operatorname{Ln}\left(G^{*} / \sin \delta\right)_{\text {short-term aged }}=\left\{\begin{array}{l}
11.2820-0.1899 A+0.0138 B+0.0004 A^{2}(P G 64) \\
11.2680-0.1653 A-0.0804 B+0.0004 A^{2}(P G 76)
\end{array}\right.
\end{gathered}
$$

where $A$ and $B$ are the test temperature $\left({ }^{\circ} \mathrm{C}\right)$ and Rediset content (\%), respectively. In these mathematical equations, insignificant factors were eliminated. According to the regression coefficients of Eqns (6) and (7), Rediset content has a positive effect on $\operatorname{Ln}\left(\mathrm{G}^{*} / \sin \delta\right)$ for PG64, while its effect is negative for PG76. It shows a recognizable interaction effect between binder type and Rediset content. Predicted and actual values of $\operatorname{Ln}\left(\mathrm{G}^{*} / \sin \right.$ $\delta$ ) are shown in Figure 5. The closeness of the predicted and actual values to the 1:1 line illustrates the predictive capability of the models. Figure 6 shows the response surfaces for unaged conditions for both asphalt binders. A similar trend can be found for the short-term aging state.

In Figure 7(a), the interaction effect of Rediset content and test temperature is presented for PG64. The slopes of the lines for both 46 and $82^{\circ} \mathrm{C}$ are equal. This

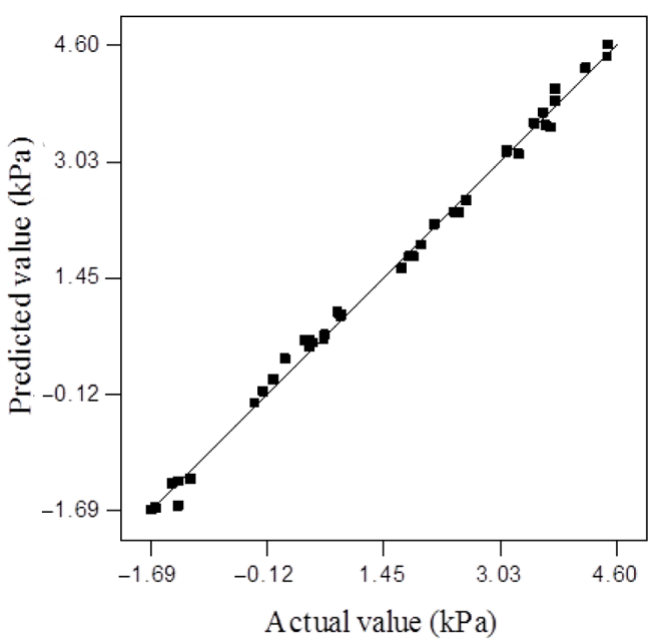

Fig. 5. Predicted and actual values of $\operatorname{Ln}\left(\mathrm{G}^{*} / \sin \delta\right)$

\begin{tabular}{|c|c|c|c|c|c|c|}
\hline Title & sum of Squares & $\mathrm{DF}^{*}$ & Mean Square & $\mathrm{F}$ Value & Prob $>$ F & Model type \\
\hline Viscosity & \multicolumn{6}{|c|}{ (PG64 from $120^{\circ} \mathrm{C}$ to $160^{\circ} \mathrm{C}$ ) } \\
\hline Regression & 0.18 & 2 & 0.090 & 106.30 & $<0.0001$ & Quadratic \\
\hline Residual error & $9.860 \mathrm{E}-004$ & 8 & $1.232 \mathrm{E}-004$ & & & \\
\hline Lack of fit & 0.011 & 9 & $1.210 \mathrm{E}-003$ & 36.30 & 0.0018 & \\
\hline R-squared & \multicolumn{6}{|l|}{0.99} \\
\hline Viscosity & \multicolumn{6}{|c|}{ (PG76 from $140^{\circ} \mathrm{C}$ to $180^{\circ} \mathrm{C}$ ) } \\
\hline Regression & 0.21 & 2 & 0.10 & 31.32 & $<0.0001$ & Quadratic \\
\hline Residual error & $5.734 \mathrm{E}-003$ & 8 & 7.167E-004 & & & \\
\hline Lack of fit & 0.042 & 9 & $4.696 \mathrm{E}-003$ & 22.10 & 0.0046 & \\
\hline R-squared & 0.98 & & & & & \\
\hline \multicolumn{7}{|l|}{$\operatorname{Ln}(G * / \sin \delta)$} \\
\hline Regression & 0.22 & 2 & 0.11 & 6.59 & 0.0041 & Quadratic \\
\hline Residual error & 0.019 & 21 & $9.261 \mathrm{E}-004$ & & & \\
\hline Lack of fit & 0.52 & 23 & 0.022 & 23.15 & $<0.0001$ & \\
\hline R-squared & 0.99 & & & & & \\
\hline \multicolumn{7}{|l|}{$G^{*}(\sin \delta)$} \\
\hline Regression & 3.04 & 3 & 1.01 & 10.44 & 0.0006 & $2 \mathrm{FI} * *$ \\
\hline Residual error & 0.66 & 8 & 0.083 & & & \\
\hline Lack of fit & 1.27 & 11 & 0.12 & 2.45 & 0.2004 & \\
\hline R-squared & 0.97 & & & & & \\
\hline
\end{tabular}

Table 8. Models proposed for prediction of $\operatorname{Ln}\left(\mathrm{G}^{*} / \sin \delta\right)$ and $\mathrm{G}^{*} \sin \delta$

Notes: ${ }_{* *}^{*}$ Degree of freedom.

** Two-factor interaction model. 


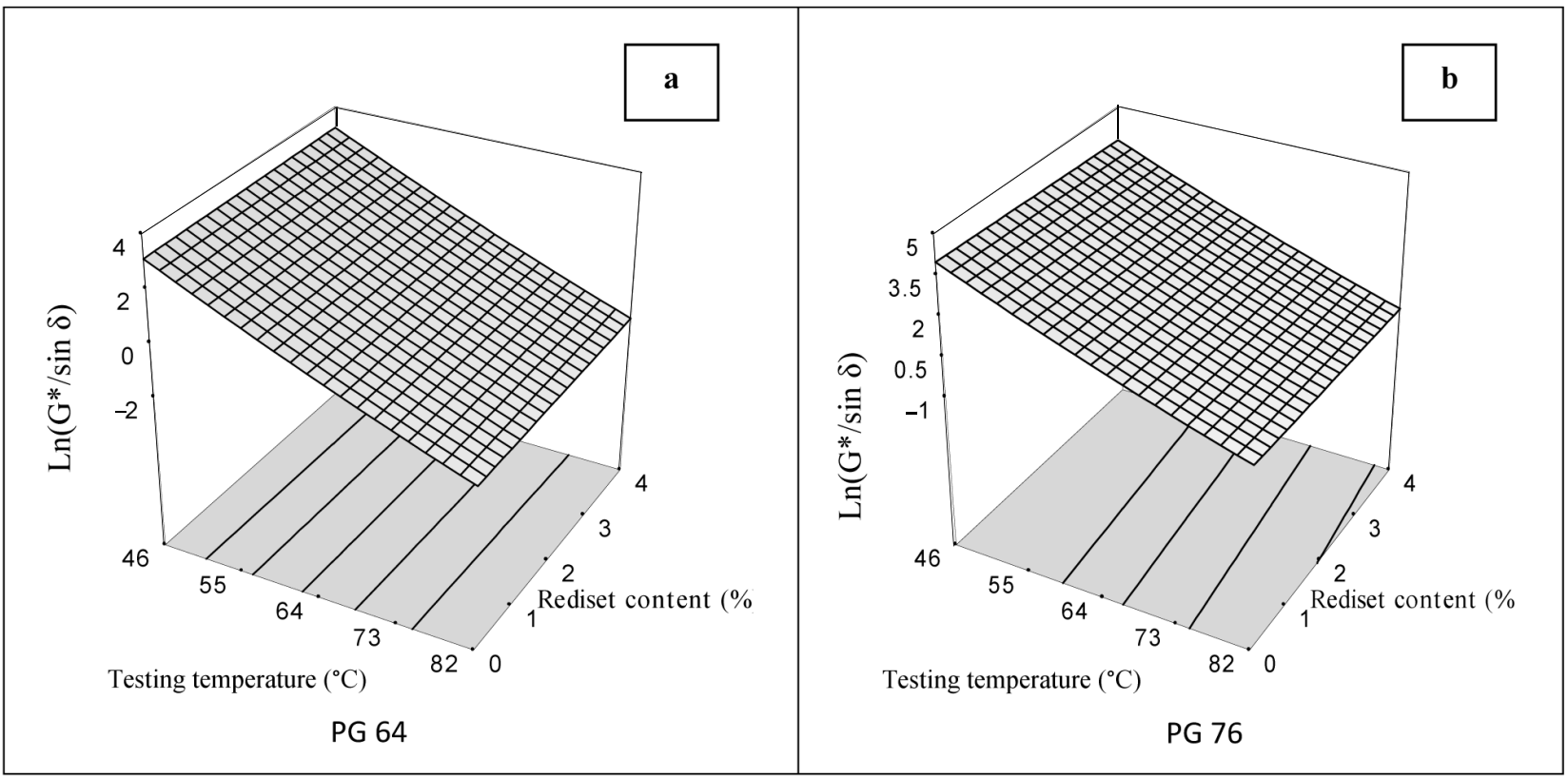

Fig. 6. Plot of response surface for the $\operatorname{Ln}\left(\mathrm{G}^{*} / \sin \delta\right)$ value for unaged conditions

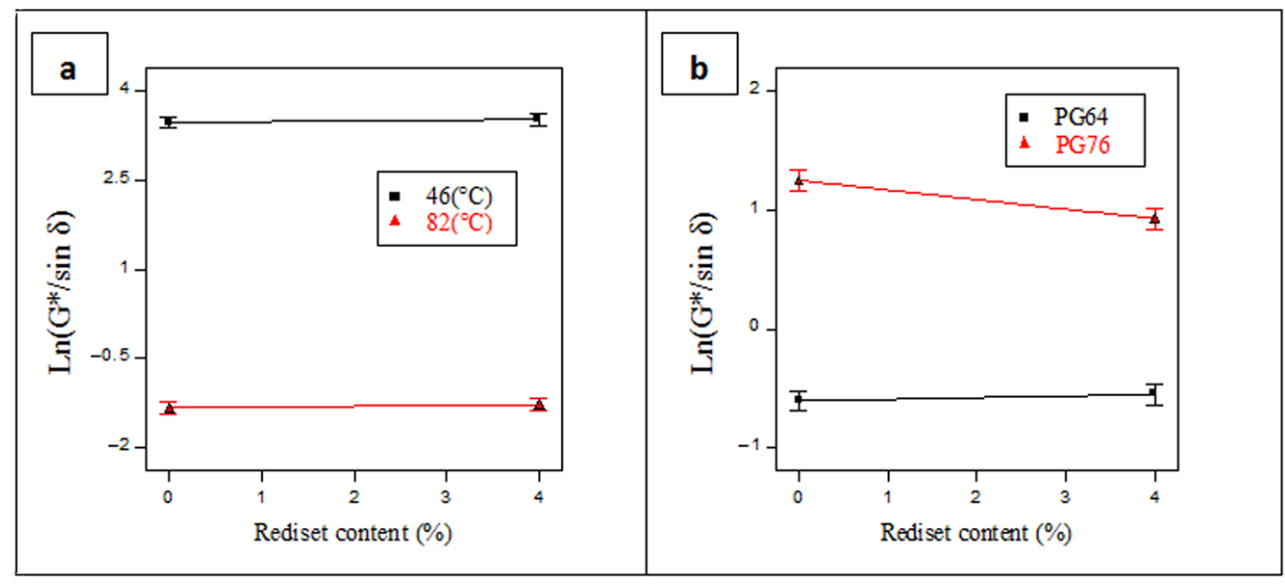

a) Short-term aged condition for PG64

b) Short-term aged condition at $76^{\circ} \mathrm{C}$

Fig. 7. Interaction effects of Rediset with temperature and binder type on the value of $\operatorname{Ln}\left(\mathrm{G}^{*} / \sin \delta\right)$ for selected conditions

fact and the ANOVA results given in Table 7 indicate that the interaction effect of Rediset content and test temperature is not statistically significant. Figure 7(b) shows the interaction effect between Rediset content and binder type for short-term aged condition at one selected temperature $\left(76^{\circ} \mathrm{C}\right)$. Increasing the Rediset content from 0 to $4 \%$ decreases the $\mathrm{Ln}\left(\mathrm{G}^{*} / \sin \delta\right)$ at $76{ }^{\circ} \mathrm{C}$ for PG76 but increases its value slightly for PG64. This indicates that an interaction between Rediset and binder type is discernible. This is confirmed by the ANOVA results given in Table 7. A similar trend exists for unaged conditions.

\subsection{Effects of Rediset on $G * \sin \delta$}

The values of $\mathrm{G}^{*} \sin \delta$ obtained from this study are given in Table 5. As can be seen, for both asphalt binders under long-term aging condition, $\mathrm{G}^{*} \sin \delta$ decreases as Rediset content and test temperature increase. Higher $\mathrm{G}^{*} \sin \delta$ implies lower resistance to fatigue cracking. According to the parameters shown in Table 8 , a two-interaction factor model can be selected as a model for prediction of the $\mathrm{G}^{*} \sin \delta$. Selected models have the low p-value in the F-test, high p-value in the lack of fit test, and high R-square. Table 7 shows the ANOVA results for $\mathrm{G}^{*} \sin \delta$. From Table 7, test temperature, Rediset content, binder type, and interaction effect of Rediset content with test temperature and binder type have significant effect on the $\mathrm{G}^{*} \sin \delta$, while the interaction of binder type and test temperature is not statistically significant. Eqn (8) shows the quantification of the effect of Rediset content and test temperature under long-term aging condition for two asphalt binders using a two-factor interaction regression model: 


$$
G^{*} \sin \delta=\left\{\begin{array}{r}
9.87878-0.28257 A-0.67802 B+0.020521(A \times B)(P G 64) \\
12.34711-0.28257 A-1.13719 B+0.020521(A \times B)(P G 76)
\end{array},\right.
$$

where $A$ and $B$ are the Rediset content (\%) and test temperature $\left({ }^{\circ} \mathrm{C}\right)$, respectively. The regression coefficients of Eqn (8) show that Rediset can decrease the $\mathrm{G}^{*}(\sin \delta)$ of both asphalt binders for the long-term aged condition. This implies that Rediset improves the fatigue performance of asphalt binders based on the Superpave criteria. Fatigue cracking is controlled by limiting $\mathrm{G}^{*}(\sin \delta)$ of long term aged material to less than $5000 \mathrm{kPa}$ at test temperatures (McGennis et al. 1994). Lower $\mathrm{G}^{*}(\sin \delta$ ) implies lower fatigue cracking potential. This result is consistent with the findings by Banerjee et al. (2012) in their evaluation of the effect of long-term aging conditions on warm-mix asphalt binder incorporating Rediset and other additives. Predictive and actual values of $\mathrm{G}^{*}(\sin \delta)$ are illustrated in Figure 8. Plots of the response surfaces for the $G^{*}(\sin \delta)$ under long-term aging conditions are shown in Figure 9 for both asphalt binders.

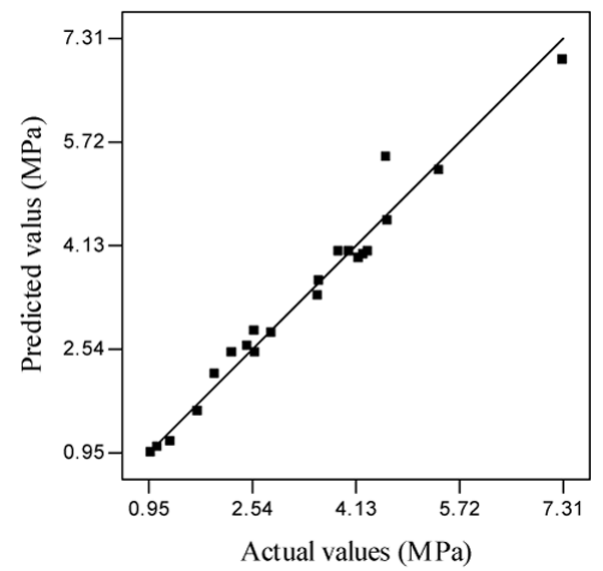

The ANOVA results in Table 7 indicate that the interaction between Rediset content and temperature is statistically significant. This is illustrated in Figure 10 for PG64 asphalt binder. When the Rediset content increased from 1 to $4 \%$ at $19{ }^{\circ} \mathrm{C}, \mathrm{G}^{*} \sin \delta$ decreased noticeably, while at $31{ }^{\circ} \mathrm{C}$, the decrease in $\mathrm{G}^{*} \sin \delta$ is not significant. This implies that using a higher Rediset content to improve fatigue performance is more effective at lower temperatures than at higher temperatures. In addition, according to Eqn (8), the interaction effect of temperature and Rediset content increases $G^{*}(\sin \delta)$. This implies that this interaction term has a negative effect on the fatigue resistance of the selected asphalt binder.

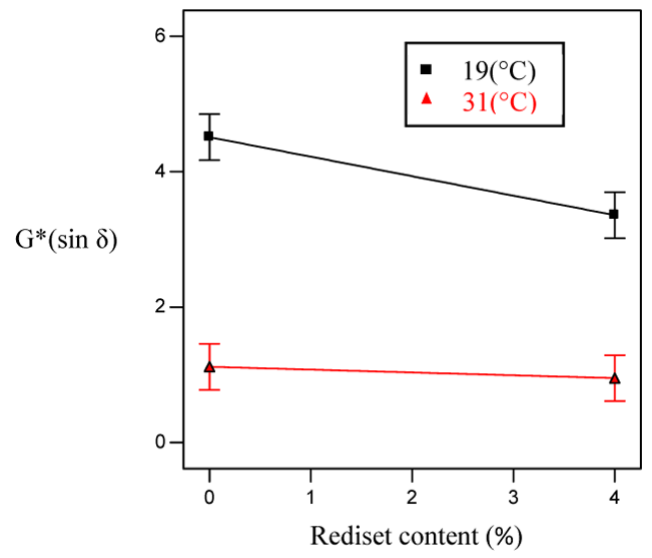

Fig. 10. Interaction effect of Rediset with temperature on the values of $\mathrm{G}^{*}(\sin \delta)$ for PG64

Fig. 8. Predicted and actual values of $\mathrm{G}^{*}(\sin \delta)$

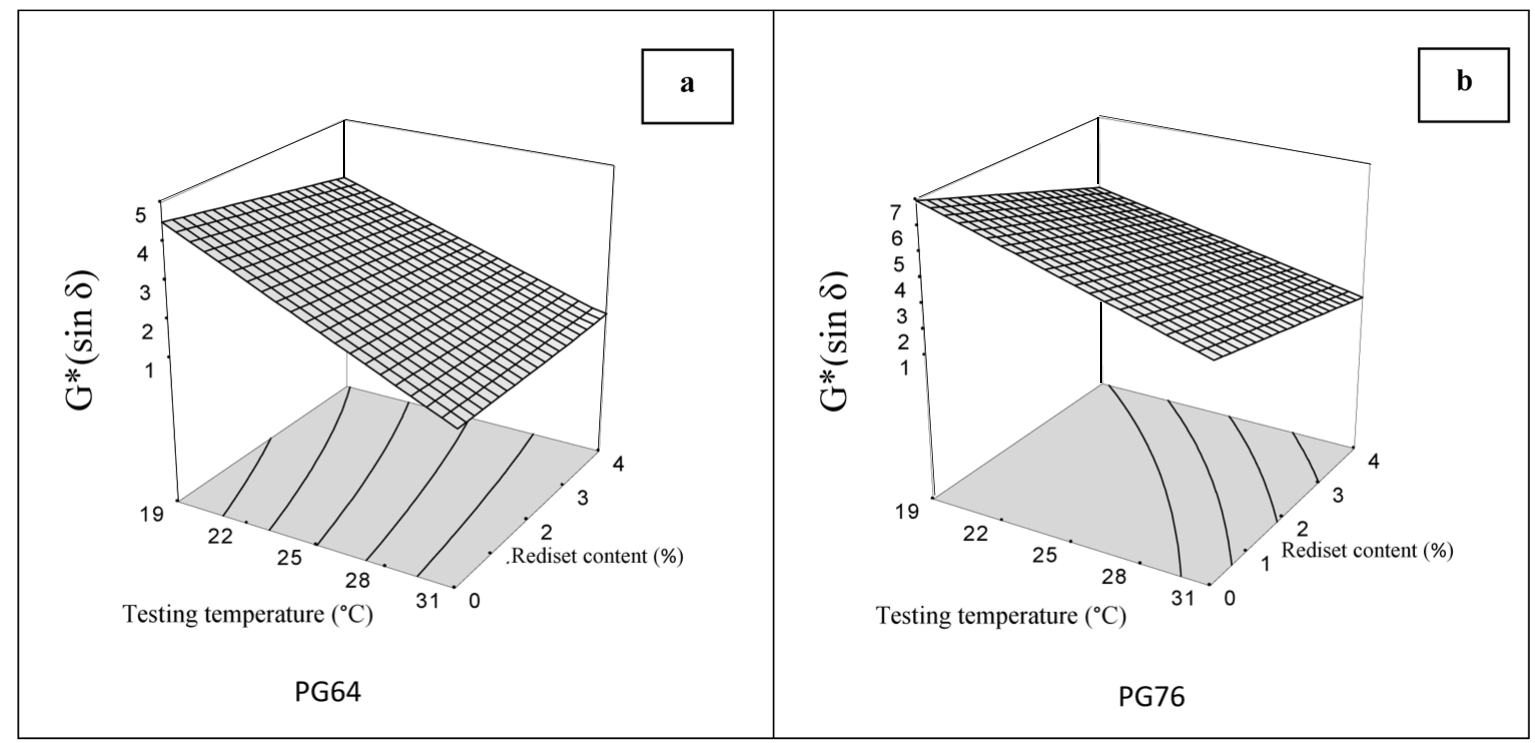

Fig. 9. Plot of response surface for $\mathrm{G}^{*}(\sin \delta)$ values for long-term aging conditions 


\section{Conclusions}

This study used RSM to develop various mathematical relationships for quantification of rheological properties of asphalt binders under different aging conditions through the evaluation of some basic parameter effects (additive contents and test temperatures) to reach a clear interpretation in characterization of asphaltic materials. In this approach instead of the evaluation of the one-factor-at-atime, the main effects and interaction effects of all factors were simultaneously and quickly evaluated via statistical methods. The test results showed that Rediset decreases the rotational viscosity of asphalt binders at very high temperatures. It improves the Superpave fatigue factor at intermediate temperatures and does not have significant adverse effects on $\mathrm{G}^{*} / \sin \delta$ at high temperatures. Therefore, the use of this additive may have acceptable potential for use in the production process of warm mix asphalt. It was also found that higher Rediset content exhibits better performance than that of lower content in terms of viscosity and $\mathrm{G}^{*}(\sin \delta)$. Although asphalt binder characterization shows some acceptable properties for this additive in terms of research responses, the authors recommend the evaluation of the detailed effects of the Rediset content on the properties of asphalt mixtures as well as its other rheological effects on asphalt binders properties. Since fatigue cracking is the main form of structural damage in flexible pavements (Nejad et al. 2013) and permanent deformations, primarily in the form of ruts, are one of the basic asphalt pavement damages (Radziszewski 2007), the authors recommend evaluating the effects of Rediset content on the fatigue and rutting properties of warm asphalt mixtures using RSM.

\section{Acknowledgements}

The authors would like to acknowledge the Universiti Sains Malaysia for funding this research through the Research University Grant Scheme (RUI) Grant number 1001.PAWAM.814231. Many thanks are also due to the technicians of the Highway Engineering Laboratory at the Universiti Sains Malaysia for their kind assistance.

\section{References}

Akcay, B.; Tasdemir, M. A. 2009. Optimisation of using lightweight aggregates in mitigating autogenous deformation of concrete, Construction and Building Materials 23(1): 353-363. https://doi.org/10.1016/j.conbuildmat.2007.11.015

Arega, Z.; Bhasin, A.; Motamed, A.; Turner, F. 2011. Influence of Warm-Mix additives and reduced aging on the rheology of asphalt binders with different natural wax contents, Journal of Materials in Civil Engineering 23(10): 1453-1459. https://doi.org/10.1061/(ASCE)MT.19435533.0000315

ASTM D2872. 2006. Standard test method for effect of heat and air on moving film of asphalt (rolling thin-film oven test), in Annual book of ASTM standards, Road and paving materials.

ASTM D4402-02. 2011. Standard test method for viscosity determination of asphalt at elevated temperatures using a rotational viscometer, in Annual book of ASTM standards, Roadand paving materials.

ASTM D6521. 2006. Standard practice for accelerated aging of asphalt binder using a pressurized aging vessel (PAV), in Annual book of ASTM standards, Roadand paving materials.

ASTM D7175-08. 2011. Standard test method for determining the rheological properties of asphalt binder using a dynamic shear rheometer, in Annual book of ASTM standards, Roadand paving materials.

Banerjee, A.; De Fortier Smit, A.; Prozzi, J. A. 2012.The effect of long-term aging on the rheology of warm mix asphalt binders, Fuel 97: 603-611. https://doi.org/10.1016/j. fuel.2012.01.072

Bennert, T.; Maher, A.; Sauber, R. 2011. Influence of production temperature and aggregate moisture content on the initial performance of Warm-Mix Asphalt, Transportation Research Record 2208: 97-107. https://doi.org/10.3141/2208-13

Boylu, F. 2011. Optimization of foundry sand characteristics of soda-activated calcium bentonite, Applied Clay Science 52: 104-108. https://doi.org/10.1016/j.clay.2011.02.005

Chakchouk, A.; Trifi, L.; Samet, B.; Bouaziz, S. 2009. Formulation of blended cement: Effect of process variables on clay pozzolanic activity, Construction and Building Materials 23(3): 1365-1373. https://doi.org/10.1016/j.conbuildmat.2008.07.015

Chavez-Valencia, L.; Manzano-Ramírez, A.; Alonso-Guzmán, E.; Contreras-García, M. 2007. Modeling of the performance of asphalt pavement using response surface methodology-the kinetics of the aging, Building and Environment 42(2): 933-939. https://doi.org/10.1016/j.buildenv.2005.10.013

Faseeulla Khan, M. D.; Dwivedi, D. K.; Sharma, S. 2012. Development of response surfacemodel for tensile shear strength of weld-bonds of aluminium alloy 6061 T651, Materials \& Design 34: 673-678. https://doi.org/10.1016/j.matdes.2011.05.025

Goh, C. S.; Tan, H. T.; Lee, K. T.; Brosse, N. 2011. Evaluation and optimization of organosolv pretreatment using combined severity factors and response surface methodology, Biomass and Bioenergy 35(9): 4025-4033. https://doi.org/10.1016/j.biombioe.2011.06.034

Hamzah, M. O.; Golchin, B. 2013. A laboratory investigation on the rheological properties of asphalt binder containing Rediset, Journal of the Eastern Asia Society for Transportation Studies 10: 1537-1550.

Hamzah, M. O.; Golchin, B.; Tye, C. T. 2013. Determination of the optimum binder content of warm mix asphalt incorporating Rediset using response surface method, Construction and Building Materials 47: 1328-1336. $\mathrm{h}$ ttps://doi.org/10.1016/j.conbuildmat.2013.06.023

Hamzah, M. O.; Golchin, B.; Jamshidi, A.; Chailleux, E. 2015. Evaluation of Rediset for use in warm-mix asphalt: a review of the literatures, International Journal of Pavement Engineering 16(9): 809-831. https://doi.org/10.1080/102 98436.2014.961020

Khodaii, A.; Haghshenas, H.; Kazemi Tehrani, H. 2012. Effect of grading and lime content on HMA stripping using statistical methodology, Construction and Building Materials 34: 131-135. https://doi.org/10.1016/j.conbuildmat.2012.02.025

Khuri, A. I.; Cornell, J. A. 1996. Response surfaces: Designs and analyses. Marcel Dekker Incorporated.

Kim, D. H.; Jeong, E.; Oh, S. E.; Shin, H. S. 2010. Combined (alkaline + ultrasonic) pretreatment effect on sewage sludge disintegration, Water Research 44(10): 3093-3100. https://doi.org/10.1016/j.watres.2010.02.032 
Kushwaha, J. P.; Srivastava, V. C.; Mall, I. D. 2010. Organics removal from dairy wastewater by electrochemical treatment and residue disposal, Separation and Purification Technology 76(2): 198-205. https://doi.org/10.1016/j.seppur.2010.10.008

McGennis, R. B.; Shuler, S.; Bahia, H. U. 1994. Background of Superpave asphalt binder test methods. Federal Highway Administration, Office of Technology Applications.

Mason, R. L.; Gunst, R. F.; Hess, J. L. 2003. Statistical design and analysis of experiments: With applications to engineering and science. Wiley. https://doi.org/10.1002/0471458503

Nassar, A. I.; Thom, N.; Parry, T. 2016. Optimizing the mix design of cold bitumen emulsion mixtures using response surface methodology, Construction and Building Materials 104: 216-229. https://doi.org/10.1016/j.conbuildmat.2015.12.073

Nejad, F. M.; Azarhoosh, A. R.; Hamedi, G. H. 2013. The effects of using recycled concrete on fatigue behavior of hot mix asphalt, Journal of Civil Engineering and Management 19(S1): 61-68. https://doi.org/10.3846/1392 3730.2013 .801892

Radziszewski, P. 2007. Modified asphalt mixtures resistance to permanent deformations, Journal of Civil Engineering and Management 13(4): 307-315.

Shim, H. J.; Kim, J. K. 2008. Consideration of fatigue life optimization of pulley in powersteering system, Materials
Science and Engineering A 483-484: 452-455. https://doi.org/10.1016/j.msea.2006.09.188

Smiljanic, M.; Pap, I.; Tatic, U.; Strbic, M.; Milinski, S.; Markovic, B. 2011. Potentials of using the polyfunctional additive "Rediset wmx" for asphalt mixtures, in $5^{\text {th }}$ International Conference "Bituminous Mixtures and Pavements", 1-3 June 2011, Greece.

Sonebi, M.; Bassuoni, M. 2013. Investigating the effect of mixture design parameters on pervious concrete by statistical modeling, Construction and Building Materials 38: 147154. https://doi.org/10.1016/j.conbuildmat.2012.07.044

Srinivasa, P.; Ravi, R.; Tharanathan, R. 2007. Effect of storage conditions on the tensile properties of eco-friendly chitosan films by response surface methodology, Journal of Food Engineering 80(1): 184-189. https://doi.org/10.1016/j.jfoodeng.2006.05.007

Xiao, F.; Punith, V.; Amirkhanian, S. N. 2012a. Effects of nonfoaming WMA additives on asphalt binders at high performance temperatures, Fuel 94: 144-155. https://doi.org/10.1016/j.fuel.2011.09.017

Xiao, F.; Amirkhanian, S. N.; Zhang, R. 2012b. Influence of short-term aging on rheological characteristics of nonfoaming WMA binders, Journal of Performance of Constructed Facilities 26(2): 145-152. https://doi.org/10.1061/(ASCE)CF.1943-5509.0000223

Meor Othman HAMZAH. He is a Professor at the School of Civil Engineering, Universiti Sains Malaysia. He has been involved in several research projects and is the author of many papers in international journals and conferences and reviewer of international journals. His expertise is mainly in the field of highway materials focusing on asphalt technology.

Babak GOLCHIN. He is an Assistant Professor in Islamic Azad University, Ahar, Iran. He obtained his PhD and master degree from the Universiti Sains Malaysia, Malaysia and Iran University of Science and Technology, Iran, respectively. His research interests include asphalt technology and pavement management system.

David WOODWARD. He is a Reader in Infrastructure Engineering at the University of Ulster, Northern Ireland. For the last 14 years, he has been Head of the Highway Engineering Research Group that now forms a sub-group within the Centre for Sustainable Technologies. He got his PhD in Highway Engineering from the University of Ulster, Ireland in 1995. His research interests focuses on the aggregate performance, additives and modifiers for bituminous materials, interfacial stress, recycled materials, road noise, skid resistance and sustainable technologies. 